Jurnal Penelitian dan Pengabdian Kepada Masyarakat Bidang ilmu Pendidikan

\title{
Workshop Manipulasi Alat Peraga Matematika Untuk Guru SD Kota Langsa Aceh
}

\author{
M. Zaki' ${ }^{1}$ Anwar², Rizki Amalia ${ }^{3}$ \\ 1,2,3 Dosen Program Studi Pendidikan Matematika FKIP Universitas Samudra \\ E-mail: acutzaki@unsam.ac.id
}

Article History: Received: 2021-01-05 || Revised: 2021-02-15 || Published: 2021-03-25

Sejarah Artikel : Diterima: 2021-01-05 || Direvisi: 2021-02-15 || Dipublikasi: 2021-03-25

\begin{abstract}
This Community Service activity aims to train teachers in the manipulation of teaching aids in elementary school mathematics learning. This program uses the training method, conducted at Sidorejo Langsa Public Elementary School in Aceh. The participants consisted of 15 elementary school teachers in Langsa City. The target was elementary mathematics teachers capable of designing and manipulating teaching aids. there are four stages: (1) The preparation stage, planning the teacher as the target audience, preparing the teaching aids used, (2) The implementation phase, the activities of this stage are: props manipulation workshop (3) The final stage of this activity is in the form of evaluation, participants are given questionnaire to evaluate the workshop activities. (4) Consultation Stage. The next activity is to provide assistance to teachers to develop and manipulate teaching aids on relevant material. The result of this activity is that the teacher as a participant was very enthusiastic during the worshop, the activity of the workshop participants starting from the presence, discussion, and practice of manipulation of teaching aids was very high with a mean of 80 standard deviations of 0.89 . Then also produce some mathematical teaching aids.
\end{abstract}

Keywords: Workshop, Manipulation, Teaching Aids, Mathematics.

\begin{abstract}
Abstrak
Kegiatan Pengabdian ini bertujuan melatih guru matematika memanipulasi alat peraga dalam pembelajaran matematika di SD/MI. Metode kegiatan dilakukan dalam bentuk pelatihan dengan mengangkat beberapa materi yang disajikan dengan manipulasi alat peraga, adapun jumlah peserta terdiri dari 13 guru matematika SDdi Kota Langsa, kegiatan ini dilakukan di SD Negeri Sidorejo langsa Aceh. Target yang diharapkan adalah guru matematika SDdi Kota Langsa mampu mendesain dan memanipulasi alat peraga. Kegiatan ini terdiri atas empat tahapan: (1) Tahap persiapan yaitu merencanakan guru sebagai khalayak sasaran, persiapan alat peraga yang digunakan, (2) Tahap pelaksanaan, kegiatan tahap ini yaitu : workshop manipualasi alat peraga (3) Tahap akhir dari kegiatan ini berupa evaluasi, peserta diberikan angket untuk mengevaluasi kegiatan workshop. (4) Tahap Konsultasi. Kegiatan selanjutnya yaitu memberikan pendampingan pada guru untuk mengembangkan dan memanipulasi alat peraga pada materi yang relevan. Hasil dari kegiatan ini adalah guru sebagai peserta sangat antusias selama mengikuti worshop, aktivitas peserta workshop dimulai dari kehadiran, berdiskusi, dan praktek manipulasi alat peraga sangat tinggi dengan mean 80 simpangan baku 0,89. Kemudian juga menghasilkan beberapa produk alat peraga matematika Sekolah Dasar.
\end{abstract}

Kata kunci: Workshop, Manipulasi, Alat Peraga, Matematika.

\section{PENDAHULUAN}

Walaupun upaya peningkatan kualitas Guru matematika SD sudah lama dilakukan, namun masih ada guru yang belum mendapat kesempatan pelatihan yang memadahi atau pelatihan bagi guruguru SD inti tidak mengimbas kepada guru lain karena kegiaran KKG tidak efektif. Hasil pengamatan penulis pada mata saat mengasuh mata kuliah Kajian Masalah Pendidikan Matematika ditemukan bahwa sebenarnya sarana dan prasarana alat peraga yang sekolah dasar SD dikota Langsa sudah memadai, hanya sanya alat peraga sangat jarang digunakan dalam pembelajaran. Disamping itu, matematika memiliki objek kajian yang abstrak, sehingga banyak siswa yang 
kesulitan mempelajari matematika. Oleh karena itu, dalam proses pembelajaran, terutama sekali pada siswa dasar atau siswa yang baru pertama sekali belajar matematika, hendaknya guru membantu siswa memahami objek matematika yang abstrak melalui bantuan alat peraga. Bantuan alat peraga yang dimaksud dapat menjembatani objek matematika yang abstrak kekonkret. Memanipulasi alat peraga dalam proses pembelajaran di SD dianggap sangat sesuai dengan tahap berpikir siswa. Jika menilik usia siswa pendidikan dasar berada pada fase usia bermain, hal ini diperkuat oleh teori Piaget yang mengatakan bahwa, tingkat perkembangan berpikir siswa SD masih berada pada tahap operasi konkrit (Paul Suparno, 2001).

Banyak sumber yang menjelaskan bahwa alat peraga berperan sebagai jembatan dari konkret ke abstrak (Heddens dalam Marshall, 2008 dan Kelly, 2006). Dalam hal ini bahasa memainkan peranan penting dalam membantu siswa untuk membuat jembatan dari konkret ke abstrak tersebut (Kelly, 2006). Melalui alat peraga dapat dikembangkan interaksi di kelas, sehingga pembelajaran matematika menjadi menyenangkan dan pemahaman siswa menjadi lebih meningkat. The National Council of Teachers of Mathematics (NCTM) juga menegaskan tentang penggunaan alat peraga dan representasi visual sangat penting dalam pembelajaran matematika (NCTM, 2000). Disamping itu, guru juga harus mengetahui waktu yang tepat, kapan, mengapa, dan bagaimana sejatinya menggunakan alat peraga, sehingga penggunaan alat peraga yang telah dirancang dengan baik dan pemahaman guru yang baik terhadap materi terkait alat peraga, akan berakibat pada pemahaman konsep yang baik oleh siswa (Rahmah, 2013). Penelitian (Salasyiah, 2018) terhadap guru matematika menunjukkan bahwa ada guru matematika pada saat menggunakan alat peraga tidak sampai pada tahap rumus matematika yang dipelajari.

Berdasarkan uraian di atas, penggunaan alat peraga perlu dirancang dan dilaksanakan oleh guru-guru dalam meningkatkan pemahaman siswa terhadap matematika. Oleh sebab itu guru-guru sekolah SD perlu sekali dibekali tentang desain dan penggunaan alat peraga tepat dengan dilakukan workshop atau pelatihan alat peraga. Adapun rumuan masalah pada kegiatan ini adalah bagaimanakah aktivitas guru sebagai peserta selama menikuti workshop manipulasi alat peraga matematika? Bagaimanakah respon guru-guru peserta workshop selama mengikuti workshop manipulasi alat peraga matematika?

Sasaran sekolah mitra pada kegiatan pengabdian ini adalah Guru SD yang ada di Kota Langsa yang tergabung dalam KKG Teuku Umar. Kegiatan ini dilaksanakan di Sekolah Dasar Negeri Sidorejo Kecamatan Langsa Lama Kota Langsa Aceh,

\section{METODE KEGIATAN}

Kegiatan Pengabdian ini dibuat untuk membekali guru-guru SD sekolah mitra yang ada di Kota Langsa, dalam bentuk kegiatan workshop manipulasi alat peraga matematika. Metode kegiatan pengabdian ini dilaksanakan dalam bentuk workshop/pelatihan; tahap awal, pemateri memberikan permasalahan terkait alat peraga, kajian teoritis tentang alat peraga, desain dan pengenalan alat peraga kemudian dilanjutkan dengan praktik memanipulasi alat peraga SD. Kegiatan workshop manipulasi alat peraga matematika bagi guru-guru SD di Kota Langsa telah dilaksanakan selama dua hari pada Bulan Agustus 2018. Kegiatan pelatihan ini bertempat di Ruang Kelas SD Negeri Siderejo Kota Langsa, berlangsung dari pukul 08.00 WIB hingga 16.30 WIB, hari kedua dari pukul 08.30 WIB hingga 13.00 WIB. Telah diundang guru-guru sekolah dasar untuk KKG Kota Langsa sebanyak 13 orang. Peserta yang mengikuti workshop berasal dari 8 sekolah dasar Negeri yang ada di daerah sekitaran kampus Universitas Negeri Samudra, masing-masing sekolah diwakili oleh 1 atau 2 orang guru. Peserta pelatihan didominasi oleh guru tenaga pengajar muda yang berusia 3035 tahun. Pemateri dari kegiatan workshop ini adalah Tim Kegiatan Pengabdian dari Program Studi Pendidikan Matematika FKIP UNSAM yaitu Muhammad Zaki, S. Pd.I., M.Pd. dan Anwar, S. Pd.I., M.Pd. Hari pertama, 
III. HASIL DAN PEMBAHASAN

Kegiatan pelatihan ini diawali dengan penyampaian materi terkait permasalahan dan kajian teori tentang Alat Peraga Matematika oleh Muhammad Zaki, S. Pd.I., M.Pd. dilanjutkan dengan diskusi. Pertanyaan yang muncul dari peserta workshop adalah : 1) Alat peraga yang tepat digunakan untuk menyampaikan pesan pada peserta, 2) kesulitan guru dalam mengelola alokasi waktu jika menggunakan alat peraga, 3) ketakutan guru dalam menyampaikan pesan dengan menggunakan alat peraga, dan 4) kesulitan guru membuat alat peraga yang tidak tersedia disekolah yang selalu berubah sesuai tuntutan kurikulum. Nara sumber menekankan pada definisi alat peraga, syarat-syarat alat peraga yang baik, hal-hal yang harus diperhatikan dalam memilih alat peraga, manfaat alat peraga.

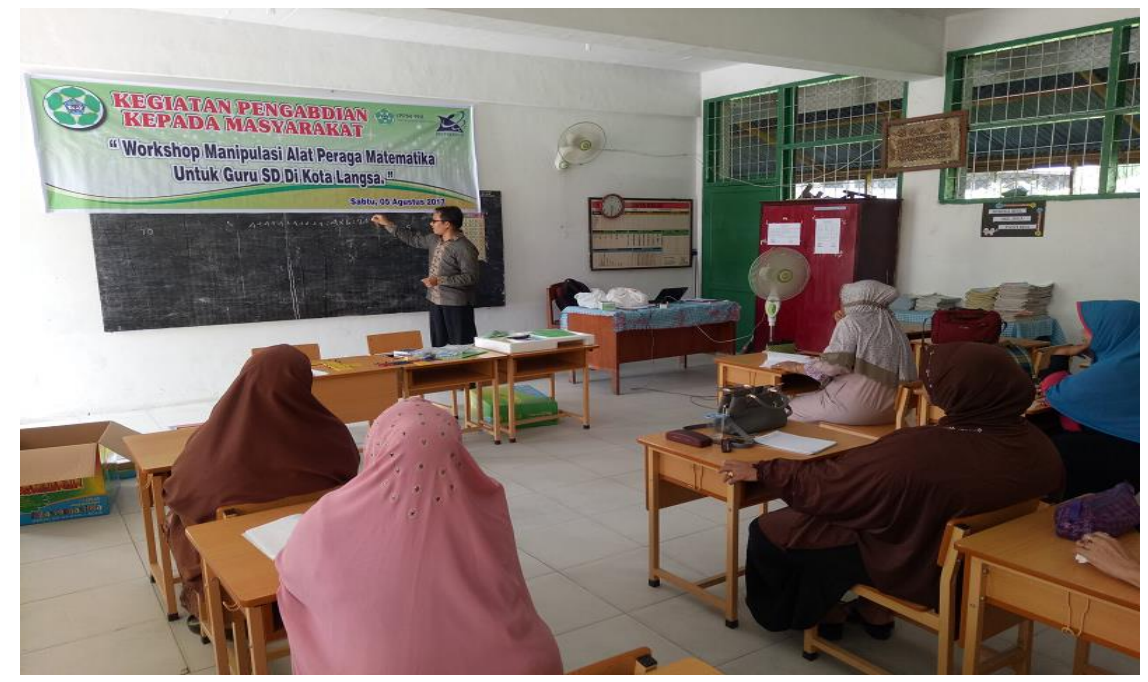

Gambar 1. Pemateri workshop menyampaikan permasalahan dan kajian teori tentang Alat Peraga Matematika

Kegiataan berikutnya dilanjutkan dengan praktik manipulasi alat peraga matematika. Pada tahap praktik manipulasi alat peraga dimulai dari disiapkan alat peraga dan bahan lainnya. Alat peraga yang disiapkan ada yang sudah dibuat oleh tim pengabdian kegiatan ini, ditambah dengan alat peraga yang tersedia di sekolah. Adapun bahan lainnya adalah Hang out manipulasi alat peraga yang akan digunakan untuk guru SD. Adapun alat-alat peraga yang dipersiapkan adalah (1) alat peraga Batang Cuisoner untuk menanamkan konsep penjumlahan, pengurangan, perkalian, pembagian bilangan serta sifat-sifatnya, Batang Cuisoner ini juga bisa untuk menanamkan konsep pemfaktoran, dan pecahan. (2) alat peraga Kertas Origami yang digunakan untuk mengkonstruksi bangun datar dan bangun ruang,(3) Detak-detak untuk menanamkan konsep penjumlahan/pengurangan bilangan yang besar. (4) Alat peraga bangun ruang untuk mengenalkan unsur bangun ruang dan luas permukaan bangun ruang dan volume bangun ruang. (5) Alat peraga Luas.

Peserta Kegiatan workshop ini dibagi empat kelompok. Setiap kelompok disediakan alat peraga. Kemudian peserta (guru) diminta untuk memanipulasi alat peraga tersebut berdasarkan ide masing-masing. Ternyata hampir semua peserta belum mengetahui tentang penggunaan alat peraga yang dibuat oleh tim pengabdian, yaitu alat peraga Batang Cuisoner dan alat peraga dari kertas origami. Untuk alat peraga lainnya yang tersedia di sekolah juga hampir sebagian guru mengetahui cara memanipulasinya. Setelah pemateri menstimulasi cara manipulasi alat peraga selanjutnya peserta bersama kelompok masing-masing manipulasi alat peraga dalam bentuk soal yang berbeda. Pemateri memonitor dan mengarahkan peserta kelompok pada saat manipulasi Alat peraga. 


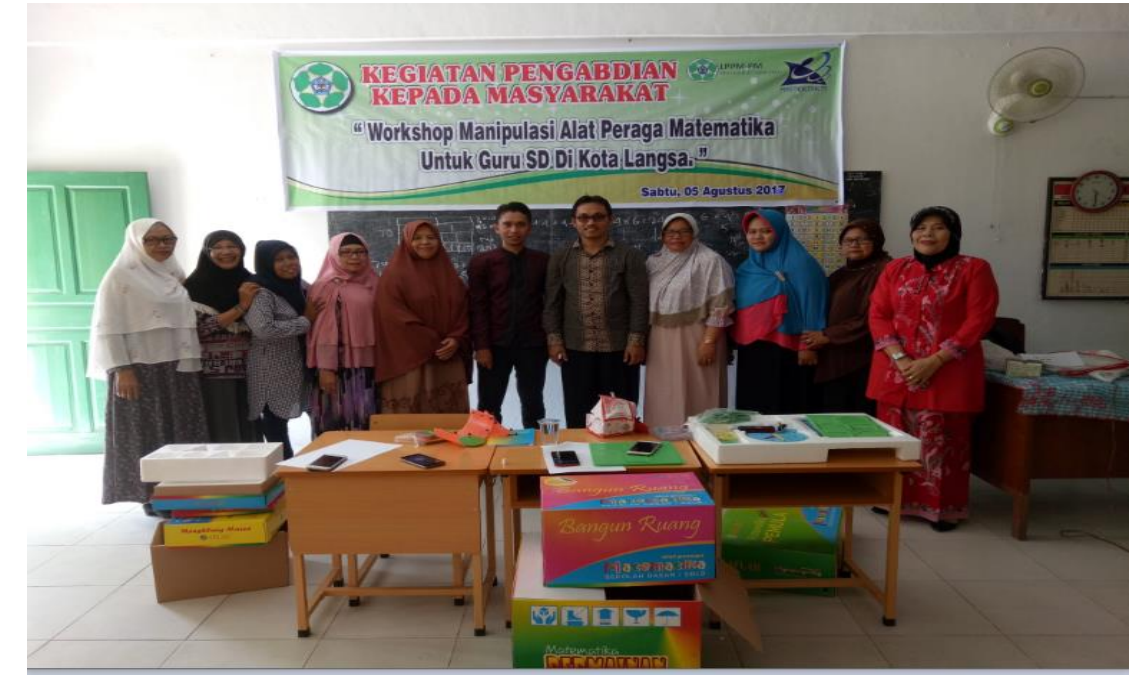

Gambar 2. Dokumentasi Pemateri, Peserta, dan beberapa alat peraga matematika Pada proses kegiatan Workshop

\section{SIMPULAN DAN SARAN}

\section{A. Simpulan}

Berdasarkan rumusan masalah, maka kesimpulan dari kegiatan ini adalah guru sebagai peserta sangat antusias selama mengikuti worshop, aktivitas peserta workshop dimulai dari kehadiran, berdiskusi, dan praktek manipulasi alat peraga sangat tinggi dengan skor rata-rata 80 simpangan baku 0,89. Respon guru-guru peserta workshop selama mengikuti workshop sangat positif. Kegiatan workshop ini menghasilkan produk artikel untuk di submid jurnal atau prosedding seminar nasional. Kemudian juga menghasilkan beberapa produk alat peraga matematika yang dipilih dan dikembangkan oleh tim pengabdian.

\section{B. Saran}

Adapun saran yang dapat direkomendasikan adalah:

1. Peserta workshop memimta menambah atau melanjutkan workshop berikutnya tentang manipulasi alat peraga SD.

2. Guru-guru memerlukan pelatihan berupa penyegaran materi matematika yang nantinya dapat meng-up grade pengetahuan mereka dari waktu ke waktu.

\section{DAFTAR RUJUKAN}

Budiman, B., \& Taufik, T. (2019). PEMBERDAYAAN MASYARAKAT PESISIR DALAM BIDANG PENDIDIKAN, KESEHATAN DAN TEKNOLOGI INFORMASI UNTUK MENDUKUNG KEMAJUAN PARIWISATA KAB. DOMPU. MEDIA BINA ILMIAH, 14(2), 2069-2076.

Johar, Rahmah (2013) Alat peraga Matematika (Manipulative for Teaching Mathematics); Makalah disampaikan pada seminar alat peraga di STAIN Malikulssaleh 23 September 2013, diakses tanggal 2 Februari 2018. Doi:10.13140/RG.2.1.2247.6240

Kelly, C. A. (2006) Using Manipulatives in Mathematical Problem Solving: A Performance-Based Analysis. In The Montana Mathematics Enthusiast, ISSN 1551-3440, Vol. 3, no.2, pp. 184-193

Marshal, L. (2008) Exploring the Use of Mathematics Manipulative Materialsin : Is It What We Think It Is? in the Proceedings of the EDU-COM 2008 International Conference. Edith Cowan University, Perth Western Australia, 19-21 November 2008. 
Salasyiah, C. I \& Zaki, M. (2018). Analisis Kemampuan Guru dalam menggunakan Alat Peraga Matematika di SMP Negeri 5 Langsa. Math Didactic: Jurnal Pendidikan Matematika,4(3),202209 https://doi.org/DOI:https://doi.org/10.33654/math.v4i3.115

Suparno Paul. (2001) Teori Perkembangan KognitifJean Piaget. Yogyakarta: Kanisius.

Yasin, I. (2020). Efektivitas Belajar Al-Qur'an Dengan menggunakan Aplikasi Hijaiyah Berbasis Budaya Lokal "Nggahi Mbojo"(Bahasa Bima) Pada Lansia di Kabupaten Dompu. Ainara Journal (Jurnal Penelitian dan PKM Bidang Ilmu Pendidikan), 1(1), 24-30. 